\title{
Gramática de valências e sintaxe dialetal no âmbito galego-português: alguns exemplos práticos
}

\author{
Xosé Manuel Sánchez Rei ${ }^{1}$
}

Recibido: 1 de outubro de 2019 / Aceptado: 20 de maio de 2020

Resumo. Desde o seu aparecimento como disciplina linguística no século XIX, a dialetologia centrou-se de preferência en fenómenos fonéticos, morfológicos e lexicais. A sintaxe, apesar da sua relevância como uma das componentes centrais da gramática, esteve praticamente esquecida nos trabalhos dialetológicos clássicos, e não só no espaço galegoportuguês, mas também noutras línguas. A gramática de valências, uma das mais relevantes escolas linguísticas do século XX, pode favorecer a investigação de fenómenos sintáticos dialetais. Para isto, deve partir-se da importância sintática e das caraterísticas semânticas dos verbos e ver como as variações dialetais se manifestam nos quadros predicativos deles.

Palavras chave: dialetologia; espaço linguístico galego-português; gramática de valências; sintaxe.

\section{[es] Gramática de valencias y sintaxis dialectal en el ámbito gallego-portugués: algunos ejemplos prácticos}

Resumen. Desde su aparición como disciplina lingüística en el siglo XIX, la dialetología se centró preferentemente en fenómenos fonéticos, morfológicos y lexicales. La sintaxis, a pesar de su relevancia como una de las componentes centrales de la gramática, estuvo practicamente olvidada en los trabajos dialetológicos clásicos, y no solo en el espacio gallego-portugués, sino también en otras lenguas. La gramática de valencias, una das más relevantes escuelas lingüísticas del siglo XX, puede favorecer la investigación de fenómenos sintácticos dialectales. Para ello, debe partirse de la importancia sintáctica y de las caraterísticas semánticas de los verbos y ver como las variaciones dialectales se manifestan en sus cuadros predicativos.

Palabras clave: dialectología; espacio lingüístico gallego-portugués; gramática de valencias; sintaxis.

\section{[en] Grammar of Valences and Dialect Syntax in the Galician-Portuguese Realm: some Practical Examples}

Abstract. Since its emergence as a linguistic discipline in the 19th century, Dialectology focused especially on pho-
netic, morphological and lexical phenomena. Syntax, despite its importance as one of the central components of the
grammar, was practically forgotten in the classic works of Dialectology, and not only in the Galician-Portuguese space,
but also in other languages. The Grammar of Valences, one of the most relevant language schools of the 20th century,
can favor the investigation of dialectal syntactic phenomena. To do this, we must start from the syntactic importance
and semantic characteristics of the verbs and see how the dialectal variations are manifested in their predicative frames.

Keywords: Dialectology; Galician-Portuguese Linguistic Space; Grammar of Valences; Syntax.

Sumário. 1. Introdução. 2. A pesquisa dialetológica no marco teórico da gramática de valências. 2.1 Sintaxe, dialetologia e modelos teóricos. 2.2. Questões gerais do modelo da gramatica de valências. 2.3. A análise dialetal desde a GV. 2.3.1. Modificação do número de atantes. a) Ampliação. b) Redução. 2.3.2. Modificação da tipologia dos atantes. 2.3.3. Modificação das caraterísticas sémicas dos atantes. 3. Conclusões. 4. Referências bibliográficas.

Referência normalizada: Sánchez Rei, X. M. (2020): "Gramática de valências e sintaxe dialetal no âmbito galego-português: alguns exemplos práticos”, em Madrygal. Revista de Estudios Gallegos 23, pp. 315-333.

1 Universidade da Corunha. Departamento de Letras, Grupo ILLA.

Correio-e: sanrei@udc.gal/x.m.sanchez.rei@udc.es; https://orcid.org/0000-0002-0763-9793. 


\section{Introdução}

Desde os mais antigos textos escritos, como alguns livros do Antigo Testamento, outros da tradição clássica helénica ou determinadas obras da literatura da Índia, existe constância da variação das línguas (cf. Marquilhas 1996: 563; Sánchez Rei 2011: 130-136). Porém, o certo é que a disciplina humanística conhecida como dialetologia nasceu em finais do século XIX, num contexto sócio-cultural muito concreto, herdeiro das atmosferas romantistas e historicistas nas quais o interesse pelo popular e pelos elementos mais idiossincráticos das nações deram forma a um importante alvo de atenção. Nesses primeiros momentos, e durante uma boa parte da seguinte centúria, o novo ramo do conhecimento preocupou-se de preferência pelas variedades de caráter diatópico ou regional e pelo estudo dos falares rurais, deixando de parte, até não há muito, as variedades urbanas. Estas eram consideradas propositadamente menos puras que as camponesas, as quais, em contrapartida, foram percebidas como as salvaguardas que melhor garantiam as formas mais genuínas da língua. Os trabalhos pioneiros de Georg Wenker (18521911) para os territórios de fala alemã, as investigações de Jules Gilliéron (1854-1826) e Edmond Edmont (1849-1926) para a língua francesa ou mesmo as pesquisas de Karl Jaberg (1877-1958) no âmbito da Italo-Romania e de Jakob Jud (1882-1952) no caso da Suíça tiveram, no elementar, esse tipo de orientação. A descompensação no grau de conhecimento ao compararmos as variedades rurais e as citadinas chegou até aos nossos dias, em que se evidencia facilmente um grande desequilíbrio se compararmos o volume de literatura especializada que se ocupou dos falares das cidades com aquele que se centrou nos locoletos rurais.

Relativamente aos fenómenos linguísticos analisados, a dialetologia mais clássica consagrou-se de maneira maioritária ao estudo das variantes fonéticas, morfológicas e lexicais, de forma que outros campos de pesquisa terminaram por ser, com o passar do tempo, pouco ou nada explorados. No caso do galego, por exemplo, muito embora haja uma certa consciência de a prosódia possuir traços locais que fazem diferente a entoação das Rias Baixas a respeito de outras regiões do país, ainda não existe uma tentativa de classificação paralela à de certos fenómenos morfológicos, como por exemplo a complexidade morfemática do verbo, conforme se pode ver em ILG (1990).
Do mesmo modo, se bem que certos MDs e/ ou partículas textuais podem ser identificados com facilidade a serem exponentes de determinadas zonas (ché, né, ou?, hom, etc.; cf. Sánchez Rei 2016: 110-118), também não existe uma tipologização geográfica deles equivalente à elaborada para os morfemas verbais, para os paradigmas de certos pronomes ou para a flexão nominal de número, segundo se deduz do exposto em ILG (1995).

A falarmos em caminhos pouco transitados pela dialetologia no tocante a outras disciplinas linguísticas, um ramo do saber que se viu claramente prejudicado foi a sintaxe. Assim, o estudo da variação dialetal no âmbito sintático tem sido um campo escassamente tratado, o que fez com que hoje em dia haja uma quantidade de informação notabilissimamente menor que a disponível para a fonética, a fonologia ou o vocabulário. Repare-se, neste sentido, no facto de os trabalhos antes citados de ILG (1990, 1995) ou de Fernández Rei (2003) pensados para o galego se centrarem quase em exclusiva em aspetos fonéticos e morfológicos. Por seu turno, os conhecidos contributos compilados em Cintra (1995), uma obra referencial na linguística galego-portuguesa, desenvolvem unicamente questões de pronúncia e de léxico. Mais inovadora se torna a proposta de Segura (2013) para o âmbito lusitano, a qual, a se basear em dados provenientes do ALEPG e do CORDIAL-SIN (cf. Martins 2000-), aborda alguns conteúdos sintáticos de adscrição geográfica, posto que a maioria continue a ter as já citadas disciplinas linguísticas da fonética e da morfologia como alvos preferenciais.

Temos de notar que este estado de coisas não se dá só no espaço galego-português, mas também no caso de outras línguas, nas quais a sintaxe dialetal tem tradicionalmente seduzido muitas menores atenções. Chambers e Trudgill (1994: 151), por exemplo, a tratarem das isoglossas que delimitam fenómenos sintáticos, não hesitam em assinalar que são bastante raras " $y$, de hecho, su aparición, incluso en las más voluminosas recopilaciones de datos dialectales, es probablemente tan escasa y esporádica que con muy poca frecuencia han sido estudiados con detenimiento"; concluem a denunciar que não "existen ni tan siquiera aproximaciones sobre cómo se deberían ordenar entre sí [as isoglossas sintáticas] o con respecto a otros tipos de isoglosas". Mais uma obra em que se aprecia para o inglês essa desproporção entre sintaxe dialetal e fenómenos fonéticos e vocabulares é o trabalho de Upton 
e Widdowson (2006), em que, de um total de 90 mapas centrados nos dialetos da atual Inglaterra, apenas três desenvolvem assuntos estritamente sintáticos ${ }^{2}$. E junto ao português e ao inglês, o espanhol, outra das línguas europeias mais faladas no mundo, apresenta uma situação similar, já que, se tivéssemos em conta os trabalhos editados por Alvar (1999), também se poderia corroborar o escasso interesse que suscitaram os fenómenos dialetais em sintaxe, quando menos na península ibérica.

Trata-se, a nosso ver, de uma situação paradoxal se reparamos na importância nuclear da sintaxe como disciplina integrante da gramática. Apesar da complexidade semântica que traz consigo o termo gramática, apesar também de esta ter sido lecionada durante muitos séculos como técnica em vez de ser percebida como uma ciência e apesar, igualmente, da quantidade de modelos teóricos que emergeram no século $\mathrm{XX}$, um dos vínculos mais estreitos e que mais rapidamente se estabelecem com a reflexão gramatical é aquele que se marca com a sintaxe, e vice-versa, já que, quando se debate sobre o que significa sintaxe, inicialmente 'ordem', a relação com a gramática aparece entre as primeiras associações. De facto, ainda que mesmo na atualidade haja hesitações a respeito das partes de que se compõe a gramática ou relativamente ao status que apresentam dentro dela-como por exemplo a morfologia, a fonética, a formação de palavras ou a semântica-, não há nem tem havido qualquer tipo de dúvidas no tocante a considerar a sintaxe como uma das suas disciplinas centrais ou até a sua disciplina por excelência. Inclusive, para autores integráveis nas correntes formalistas ou próximos delas, o estudo da gramática deve basear-se principalmente na investigação em sintaxe. E mesmo a centralidade desta dentro da pesquisa gramatical tem provocado que o conceito sintaxe se tivesse confundido com o de gramática (cf. Dubois et al. 2007: 559, s.v. sintaxe).

Sendo, pois, uma disciplina tão relevante, surpreende essa pouca dedicação nos estudos sobre variação dialetal. Ao interessarmo-nos pelas causas desta situação de desequilíbrio, surgem vários motivos suscetíveis de serem resumidos como se segue. Em primeiro lugar, consoante Francis (1989: 41), é certo que a sintaxe, até tempos mais ou menos recentes, não teve uma atenção equivalente à dedicada a outras disciplinas linguísticas e, inclusive, caso fosse comparada com a morfologia, poderia detetar-se com facilidade uma notória descompensação orientada favoravelmente para esta última $^{3}$. Em segundo lugar, continuando com o assinalado por Francis, o estudo dos dialetalismos sintáticos solicita "larger samples of language than it has been convenient or even possible to collect by the usual methods". Em terceiro lugar, a variação sintática, até a diatópica, com frequência é percebida como um traço positivo de estilo que deve potenciar-se mesmo, quando menos na linguagem literária ou no standard; nas aulas do ensino é costume aconselhar o alunado para que seja coerente nas duplas possibilidades morfológicas existentes em determinados fenómenos da língua padrão (cf., por exemplo, De um modo ou de outro Dum modo ou doutro, Em uma viagem Numa viagem, etc.), mas em sintaxe, pelo contrário, costuma-se recomendar a variação e exorta-se o estudantado a alternar diferentes construções (cf. Cumpre que venhas C Cumpre vires, Tem de o fazer $\sim$ Tem que o fazer, etc.). E em quarto lugar, derivado precisamente da existência de diversas possibilidades de estruturação frásica e clausular, devemos sublinhar que nem sempre as variações sintáticas se fazem notar com a mesma regularidade que outros tipos de

2 Em concreto, são o mapa 26, que recolhe as construções do verbo to give e a ordem na cláusula dos seus objeto direto e indireto (give it me give me it $\sim$ give it to me; etc.); o mapa 31, a expor a variação de um grupo integrado por um pronome pessoal (sujeito ou complemento empregado como sujeito) e um numeral (there are just we two us two $\sim$ two of us $\sim$ the two of us, etc.); e o mapa 76, o qual sintetiza as possibilidades de flexão da primeira pessoa do plural do presente do indicativo do verbo to be e os pronomes que se comportam como sujeito (oh yes we are we bin $\sim$ us be $\sim$ we am, etc.). Cf. Upton e Widdowson (2006: 64-65, 74-75 e 76-77).

3 Neste sentido, encaixam as palavras de Cidrás Escáneo (2005: 339) ao denunciar a centralidade da descrição morfológica nos estudos de gramática quando fala de "morfocentrismo das gramáticas tradicionais". Veja-se também o exposto em Cidrás Escáneo e Dubert García (2017: 119-121): “A sintaxe ocupou en xeral un lugar pouco relevante no plan de traballo das gramáticas galegas ata hoxe, oscilando entre a simple ausencia e unha presenza marxinal e fragmentaria [...]. A día de hoxe, o coñecemento da sintaxe do galego segue a presentar, na súa intrínseca complexidade, importantes desequilibrios, con áreas relativamente ben estudadas e outras descritas de maneira moi deficiente ou carentes de estudos". 
variantes: se a pronúncia do substantivo hora conhece na Galiza duas possibilidades relativamente sistemáticas no território (['ora] na metade ocidental e (['ora] na metade oriental), estruturas como Tenho que o fazer, Tenho-o que fazer ou Tenho que fazê-lo se tornam mais difíceis de se adscreverem geograficamente ${ }^{4}$.

Aliás, não se deve perder de vista uma outra causa, talvez tão importante ou mais que as quatro anteriores, como é a (relativa) estabilidade da sintaxe, já que se trata de um campo em que as modificações se tornam menos percetíveis para a comunidade de falantes. As diferenças sintáticas de caráter dialetal evidenciam-se com maior dificuldade do que as existentes para as restantes esferas da descrição linguística, daí que Pottier (1999: 32), neste sentido, assinalasse como a sintaxe se torna pouco "reveladora de áreas específicas"s. Mesmo em estudos especializados se tem recorrentemente remarcado a pouca entidade da variação sintática dialetal a respeito da sintaxe geral da variedade padrão: nos inícios do século XX, Vasconcellos (1987: 121) afirmava que a "syntaxe populaire ne diffère pas essentiellment de la syntaxe litérarie" e Florêncio (2001: 72), cem anos mais tarde, não hesita, ao referir-se aos traços dos falares do Alentejo, em fazer um comentário facilmente extrapolável a outras regiões de Portugal e da Galiza, o qual condiz com Vasconcellos ao ponderar que a sintaxe dialetal pouco se diferencia "da da língua normal".

Mas a importância da variação e mudança sintática e o seu escasso tratamento desde a dialetologia parece ver-se compensada, de alguma maneira, pela abordagem que se faz dela noutras disciplinas ou pela transcendência que se lhe concede em determinadas esferas de conhecimento. Eis dois exemplos ao respeito: em primeiro lugar, a nos deslocarmos para perspetivas sociolinguísticas, a sintaxe corresponderia a uma marca de coesão social da comunidade de falantes, o elemento capaz de a compatar; contrastivamente, outros saberes gramaticais incidiriam no sentido contrário, isto é, em elementos de diferenciação: o vocabulário perceber-se-ia como um indício de divisões verticais na sociedade (estrato, nível de educação, relações sociais, etc.), ao passo que a pronúncia se ocuparia de refletir o grupo social permanente com que os membros da comunidade se identificariam ou a que quereriam equiparar-se (cf. Hudson 1981: 58).

E em segundo lugar, desde disciplinas como a neurolinguística ou psicolinguística, a sintaxe é valorizada por se constituir com muita frequência num elemento revelador das caraterísticas dos indivíduos em momentos singulares. Quando aparecem nas pessoas problemas de saúde causados por diversas patologías (demências senis, mal de Alzheimer, etc.), as alterações em sintaxe são umas das primeiras evidências de qualquer coisa não estar a funcionar corretamente por causa das afasias (cf. Jódar Vicente 2005: 111-120). Nas diferentes fases dessas doenças, tornam-se fáceis de se documentarem -para além de disfunções na expressão oral, na interpretação semântica e pragmática dos textos ou na produção leto-escritora-, alguns fenómenos que verificam tais afetações linguístico-cognitivas no que se denomina "agramatismo" e "paragramatismo" (cf. Benedet 2006: II, 4762) $)^{6}$ : anacolutos gramaticais, esvaecimento do processo de construção sintática, perda do fio discursivo no eixo semântico-sintático, perda da relação de concordâncias entre os elementos frásicos e/ou clausulares, reiterações desnecessárias, interpretabilidade semântica duvidosa, problemas na compreensão argumental dos verbos canto ao número de atantes e tipos de complementação, etc.

4 Não assim contextual, etária ou literariamente, pois uma construção como Tenho que o fazer é sentida no geral como mais própria de variedades de gente idosa, ao passo que também é percebida como marca positiva de estilo. Cf. Freixeiro Mato (2013: 381-382) quando expõe que o "modelo de lingua culta [para o galego] que se está a conformar tende a privilexiar a posición do clítico entre o nexo e a forma infinita do verbo [...], segundo de facto aconsellan algúns manuais de estilo ou similares [...] e segundo tamén acontece con relativa frecuencia na lingua literaria".

5 Contudo, o contato com outros idiomas ou variedades pode ser um fator capaz de explicar certos pormenores da falta de coincidência sintática entre modalidades da mesma língua. Assim, a tratar a variação do espanhol, este mesmo autor (Pottier 1999: 32) expus alguns casos singulares em que o convívio com línguas americanas, nas quais há com frequência estruturas sintáticas diferentes dos sistemas românicos (e mesmo indo-europeus), era capaz de explicar fenómenos de variação sintática diatópica.

6 Talvez interesse salientarmos aqui que o termo agramatismo já dispõe de uma certa tradição nos estudos linguísticos, pois começou a ser utilizado nos primórdios do século XIX, quando Joseph-Philippe-François Deleuze (17531835), o empregou em 1819 em para designar qualquer alteração da produção das cláusulas "observadas en pacientes afásicos" (cf. Benedet 2006: II, 50). 
Em definitivo, a sintaxe ocupou tradicionalmente um lugar secundário nos estudos sobre variação dialetal, muito embora a sua relevância não justifique essa lateralização. Isto manteve-se, com maior ou menor evidência, até à segunda metade do século XX, conforme veremos na seguinte secção.

\section{A pesquisa dialetológica no marco teórico da gramática de valências}

\subsection{Sintaxe, dialetologia e modelos teóricos}

Uma rápida olhada às diferentes disciplinas e orientações linguísticas faria com que ninguém pudesse negar os largos espaços de confluência entre as pesquisas dialetológicas e certos âmbitos de investigação: os estudos dialetais maridam com notória facilidade com áreas da gramática histórica (cf. Mariño Paz 1994) ou com a toponomástica (cf. Sánchez Rei 2013), por exemplo. Mas essas evidências seriam menos fáceis de serem assumíveis se se procurassem as tais esferas de confluência com algumas escolas linguísticas de larga projeção académica na época contemporânea. Com efeito, durante o século XX manteve-se entre a investigação dialetal e as diferentes correntes linguísticas um afastamento metodológico e epistemológico que só principiou a dar mostras de involução muito serodiamente, a partir da segunda metade da passada centúria. Duas das correntes que melhor deram conta desta situação de falta de espaços partilhados foram os modelos do estruturalismo e as do formalismo.

Até aos meados do século XX, a maior parte da literatura especializada nas correntes estruturalistas partia do suposto de que um sistema linguístico tinha de se explicar por si próprio, sem referência a outros sistemas, mesmo que fossem variedades dialetais. Os fonemas, por exemplo, cobravam sentido em comparação ou em confronto com outros fonemas (a vogal central aberta /a/ a respeito de outras, o fonema consonântico oclusivo velar vozeado $/ \mathrm{g} /$ relativamente a diferentes consoantes, etc.). Dava-se o paradoxal caso de que, como a dialetologia também se baseia na comparação de variantes, existia uma grande tendência entre linguistas a ignorarem as pesquisas sobre variação dialetal. Mas isto não foi impedimento para que no primeiro quartel do século XX não se comezassem a percorrer timidamente caminhos confluentes entre a dialetologia e o estruturalismo, ainda que não deixassem de ser itinerários esporádicos; notemos que já Troubetzkoy (1964: 343-350), durante a década de 30 , propunha investigar a pronúncia local dos mesmos fonemas para estudar as alofonias, os seus limites e o número de fonemas de cada variedade com o objetivo de analisar as divergências fonológicas entre cada dialeto. No entanto, a partir dessa época, a dialetologia e a linguística estrutural deixaram de se entender no mínimo, apesar de ser certo que o diálogo mútuo entre ambas nunca tinha sido muito fluído ${ }^{7}$.

Anos mais tarde, no ecuador do século, Weinrich (1986) expressava a hipótese de a elaboração de estudos dialetológicos congruentemente assentes nas bases teóricas da linguística estrutural ser possível. Desde aqui, alguns linguistas começaram a trabalhar na ideia de o formulamento sistemático de diferenças dialetais poder ser uma linha de aprofundamento nas pesquisas sobre variação geográfica. $\mathrm{O}$ marco teórico do estruturalismo virou, com o passar do tempo, num dos caminhos mais percorridos e "amb més impacte durant els darrers anys", de acordo com as palavras de Viaplana (2002: 118). Nesta linha, Moulton (1960) advertiu que as investigações tinham de contemplar a possibilidade da existência de sistemas dentro das variedades regionais, de forma que as variantes detetadas deviam ser analisadas não como átomos isolados, mas a fazerem parte desses presumíveis sistemas. Weinrich centrou-se na fonologia, mas deixou a porta aberta para que esta visão dos diassistemas e as suas implicações na dialetologia estrutural fossem aplicadas também a outras esferas da descrição linguística, tais como a morfologia ou o léxico; porém, a sintaxe continuava a ficar fora dessas possíveis linhas de pesquisa.

Desde as escolas formalistas, por sua vez, Campbell (1972) foi um dos pioneiros em formular a possibilidade de realizar estudos dialetais de uma perspetiva generativista, distinta

Sobre este particular, escreve Gimeno Menéndez (1990: 107-108) que a principal “objección que los estructuralistas formulaban a los dialectólogos era la ignorancia de la estrutura de los geolectos y la comparación de elementos pertenecientes a diferentes sistemas, sin tomar en consideración las relaciones de cada elemento con los otros de su sistema. Por su lado, los dialectólogos pensaban que el interés de los estructuralistas por las oposiciones y funciones lingüísticas era complicado e innecesario, cuando no deformaban los hechos reales a favor de una excesiva abstracción". 
de propostas tradicionais ou estruturalistas ${ }^{8}$. E, na verdade, mais um marco teórico aplicado à análise dialetal é o que nos proprociona a gramática generativa transformacional, que ofereceu o seu modelo epistemológico ao estudo das variedades dialetais, particularmente desde os princípios da fonologia. Para isto, convém partirmos de dois pontos fundamentais: em primeiro lugar, a existência de formas subjacentes, que são as formas fonológicas em que estão agrupadas as unidades lexicais; e em segundo lugar, a existência de regras fonológicas que transformam essas tais formas subjacentes em formas superficiais, isto é, na sua verdadeira pronúncia. Assim, a dialetologia generativa assentou na ideia de que os dialetos relacionados podem ter uma única forma geral subjacente, mas diferirem (i) nas regras fonológicas que se aplicam às formas subjacentes, (ii) nos contextos em que se praticam as regras e (iii) na ordem em que se aplicam as regras. Subsequentemente, a uma forma subjacente vão corresponder diversas formas superficiais, dependendo do grau de diversidade linguística territorial que houver. Porém, conforme expõe Francis (1989: 181), muitas regras não se aplicam automaticamente e sem exceção, mas os utilizadores da língua mudam a aplicação dessas regras "in the situation under which words are pronunced"'; o contexto, portanto, é capaz de fazer com que alguma regra se não aplique. De qualquer modo, Campbell baseou-se na fonologia, deixando de lado outras possibilidades de investigação, como, mais numa ocasião, a da componente sintática.

Outra das escolas mais representativas da linguística de finais do século XX é a teoria da valência. Ver-se-á na seguinte parte que desde os seus princípios teóricos se torna igualmente factível a elaboração de pesquisas dialetológicas, podendo entender os dialetos não estritamente como modalidades regionais no sentido mais tradicional da geolinguística, mas também como variedades linguísticas vinculadas a diversos fatores de variação (o espaço, o contexto, a idade, etc.).

\subsection{Questões gerais do modelo da gramati- ca de valências}

Dentro do amplo marco teórico estruturalista, sobranceia a corrente conhecida como gramática de dependências ou de valências (doravante GV), que teve a sua primeira formulação na clássica obra Éléments de Syntaxe Structurale, escrita pelo linguista galo Lucien Tesnière e dada a lume no ecuador do século passado $(1959)^{10}$. A transcendência da publicação desta obra não foi menor: segundo o parecer da professora Brito (1999: 17), só "será com Tesnière que se começará a desenvolver uma Sintaxe estrutural", para logo indicar que foi este autor o "iniciador na Europa das 'gramáticas de dependências' ou 'gramáticas de valências' que haveriam de dominar a cena europeia nos anos 60, 70 e parte dos anos 80." A partir daí, essa perspetiva teórica tem sofrido substanciais leituras e modernizações, sobretudo nos países da Europa do Leste. Para o âmbito da linguística lusófona destacam os estudos de Busse e Vilela (1986) -obra que aplicou pela primeira vez a GV ao português-, Neves (1999), Vilela e Koch (2001), Perini (2008), etc. Em tais contributos podem apreciar-se algumas dessas relevantes revisões, e uma delas não é nada desimportante, pois afeta a cifra de elementos argumentais ou atanciais considerados: dos três únicos atantes que figuravam na obra de Tesnière, passou-se para um número de dez, conforme se verá mais abaixo.

A GV, contrastivamente com outras correntes, centra-se na análise sintática e semântica das unidades linguísticas ${ }^{11}$. Pelo seu conteúdo semântico e sintático, as classes de palavras com que opera a GV são preferencialmente o nome substantivo, o nome adjetivo, o verbo e, em ocasiões, alguns advérbios. Precisamente é no verbo que mora, para o marco teórico da $\mathrm{GV}$, a capacidade de estruturação da cláusula e ele é o verdadeiro nó capaz de pôr em relação, mediante as suas caraterísticas semânticas, um sujeito, um complemento direto, um complemento preposicional, um complemento

8 Para um desenvolvimento da aplicação dos princípios generativistas à análise dialetal, torna-se de interesse o exposto em Francis (1989: 171-192) ou em Gimeno Menéndez (1990: 122-130).

9 Continua a advertir Francis (1989: 182): "We can only conclude that while most phonological performance goes according to fixed rules, there are areas of variation not only between different speakers of a given dialect, but within the performance of a single speaker".

10 Existe uma tradução para o espanhol em dois volumes publicada no ano 1994 pela editora Gredos.

11 Também foram percorridos outros caminhos de investigação, como uma aproximação desde a morfologia, a elaboração de dicionários de valências, a valência textual, etc. Cf. Báez San José (1988: 42, 137-139). 
indireto, etc ${ }^{12}$. O significado do verbo determina a sua "valência", termo apanhado da química, que possibilita sabermos quantos atantes ou argumentos tem o antedito verbo, se são obrigatórios ou facultativos, a sua caraterização semântico-funcional quanto aos papéis desempenhados por eles e, também, a indicação das suas funções sintáticas (cf. Dik 1989: 68-69). O termo "valência", pois, define-se como o número de lugares vazios que precisam de ser lexicalmente preenchidos para um verbo atingir uma total significação, e esse número acha-se determinado pelo próprio predicado verbal. Entregar, por exemplo, exige três lugares que têm de ser ocupados na linguagem normal do seguinte modo: $X_{1}$ [+animado] Agente, $X_{2}$ [+/-animado] Paciente e $\mathrm{X}_{3}$ [+/animado] Receptor ${ }^{13}$; se os traços sémicos desses elementos se cumprirem, obter-se-ão as cláusulas (1a-1b) e, de se não cumprirem nalgum pormenor, o produto final pode ser ilustrado com as cláusulas $(1 \mathrm{c}-1 \mathrm{~d})^{14}$ :

1. (a) A professora $a_{\mathrm{x} 1}$ entregou o exame ${ }_{\mathrm{x} 2} a \mathrm{o}$ estudantado ${ }_{\mathrm{X} 3}$

(b) A professora ${ }_{\mathrm{X} 1}$ entregou os cães ${ }_{\mathrm{X} 2}$ às cuidadoras $_{\mathrm{X} 3}$

(c) ?A professora ${ }_{\mathrm{x} 1}$ entregou o estudantado $o_{\mathrm{X} 2}$ ao exame $\mathrm{x} 3$

(d) ?O exame ${ }_{\mathrm{X} 1}$ entregou $o$ estudantado $o_{\mathrm{X} 2}$ à professora ${ }_{\mathrm{X} 3}$

Mediante a valência, portanto, sabe-se qual o número de atantes que solicita o predicado verbal, em que se distinguem, de acordo com o assinalado mais acima, até dez tipos: $\mathrm{A}_{1}$ (Sujeito),
$\mathrm{A}_{2}$ (Complemento Direto), $\mathrm{A}_{3}$ (Complemento Indireto), $\mathrm{A}_{4}$ (Complemento Preposicional), $\mathrm{A}_{5}$ (Complemento Locativo), $\mathrm{A}_{6}$ (Complemento Direcional), $\mathrm{A}_{7}$ (Complemento Temporativo), $\mathrm{A}_{8}$ (Complemento Quantitativo), $\mathrm{A}_{9}$ (Complemento Modativo) e $\mathrm{A}_{10}$ (Complemento Predicativo $)^{15}$. Comvém fazermos a esta divisão um apontamento, como é o modo em que se combinam os elementos atanciais: qualquer que for o marco predicativo de cada verbo, nunca excede os três elementos, de modo que se fala em (i) verbos avalenciais ou avalentes (sem atância) e (ii) verbos valenciais, classificados, por seu turno, em verbos monovalentes (um só atante), verbos bivalentes (dois elementos atanciais) e verbos trivalentes (três elementos atanciais). $\mathrm{O}$ verbo, portanto, torna-se a classe de palavras mais relevante na estrutura clausular, pois sem ele não há cláusula, como também não há qualquer tipo de subordinação de constituintes a esse elemento básico.

\subsection{A análise dialetal desde a GV}

Do confronto entre o marco predicativo de determinados verbos, como por exemplo carecer, depender, telefonar, etc., com o de outros, do tipo casar, dizer, dar, falar, etc., tira-se uma conclusão: ao passo que existem predicados verbais que nunca mudam a sua valência, documentam-se outros, em confronto, capazes de a modificarem com extrema facilidade. Repare-se, a este respeito, na única possibilidade de estruturação de (2a) e na inadequação dos usos nas restantes mostras $(2 \mathrm{~b}, 2 \mathrm{c}, 2 \mathrm{~d} \text { e } 2 \mathrm{e})^{16}$

12 Veja-se Lyons (1993: 100): "Hasta hoy el término 'valencia' (tomado de la química) no se ha empleado mucho en la bibliografía británica y americana sobre lingüística. Pero la noción se encuentra latente en buena parte de la teoría gramatical, aunque no aparezca funcionalmente el término. El aspecto más controvertido y novedoso de la noción de valencia [...] consiste en que desvirtúa, por así decirlo, las distinciones tradicionales entre sujeto y predicado (de la cláusula), por una parte, y entre sujeto y objeto (del verbo), por otra".

13 Cf. o modelo de análise de Dik (1989: 68-69) para o marco predicativo do verbo to give, parcialmente adaptado por nós.

14 Os exemplos referidos no geral à norma galega e à portuguesa transcrevem-se com a ortografia lusitana vigorante. Aqueles casos mais específicos ou exclusivos do galego serão reproduzidos de acordo com as Normas oficiais vigentes (cf. RAG / ILG 2003).

15 A proposta de dez atantes é também a que assinalam outros autores, muito embora a tipologização não coincida exatamente com esta. Veja-se, neste sentido, Rábade Castiñeira (2003: 144-148), que desenvolve uma interessante revisão a partir do quinto atante $\left(\mathrm{A}_{5}\right.$, predicativo; $\mathrm{A}_{6}$, locativo; $\mathrm{A}_{7}$, temporal; $\mathrm{A}_{8}$, modal; $\mathrm{A}_{9}$, situativo; $\mathrm{A}_{10}$, quantitativo). Por sua vez, desde postulados teóricos de outras escolas, é normal o falar-se em apenas quatro elementos argumentais, segundo se vê no trabalho de Porto Dapena (1997), em que somente diferencia o complemento direto, indireto, suplemento e agente.

16 Este tipo de construções de (2b-2e) são que se identificam em Peres e Moia (1995: 144-152) sob a epígrafe "substituição de preposição de argumentos de predicados verbais", título baixo o qual são citados outros exemplos como "consistir de (por consistir em), depender a (por depender de), desistir em (por desistir de), especular de (por especular sobre), impedir em (por impedir de), pactuar de (por pactuar com), partilhar de (por partilhar com), trepar em (por trepar para)". 
e, em confronto, notem-se também as múltiplas hipóteses que apresenta o verbo dar em (3): apreciam-se notabilíssimas mudanças no seu significado, o que, recolhendo uma ideia exposta em Vilela e Koch (2001: 353), faz levantar a "dúvida sobre se estamos perante o mesmo verbo" ou, pelo contrário, diante de predicados verbais diferentes ${ }^{17}$ :

2. (a) A reitora ${ }_{\mathrm{A} 1}$ telefonou à decana da faculdade $_{\mathrm{A} 3}$

(b) * A reitora $a_{\mathrm{A} 1}$ telefonou com a decana da faculdade ${ }_{\mathrm{A} 4}$

(c) $*$ A reitora ${ }_{\mathrm{A} 1}$ telefonou a decana da faculdade $_{\mathrm{A} 2}$

(d) $*$ A reitora $_{\mathrm{A} 1}$ telefonou na decana da faculdade $_{\mathrm{A} 4}$

(e) * A reitora $_{\mathrm{A} 1}$ telefonou da decana da faculdade $_{\mathrm{A} 4}$

3. (a) $A$ reitora ${ }_{\mathrm{Al}}$, depois do congresso, deu um abraço ${ }_{\mathrm{A} 2}$ à decana da faculdade ${ }_{\mathrm{A} 4}$

(b) A reitora $_{\mathrm{A} 1}$, após muito pensar, deu com a solução ${ }_{\mathrm{A} 4}$

(c) Onde é que estiveste durante estes dias? $\left[\right.$ Nós $\left._{\mathrm{A} 1}\right]$ Dávamos-te $e_{\mathrm{A} 2}$ em Coimbra ${ }_{\mathrm{A} 5}$

(d) A Rua Nova ${ }_{\mathrm{Al}}$ dá ao centro histórico da cidade ${ }_{\mathrm{A} 6}$

(e) $A$ s rosas ${ }_{\mathrm{Al}}$ dar-se-ão bem $_{\mathrm{A} 9}$ se as cui dares com atenção

(f) Com este tempo tão instável, os dias $_{\mathrm{Al}}$ não dão com os outros ${ }_{\mathrm{A} 4}$ (g) $\left[\right.$ Ela $\left._{\mathrm{A} 1}\right]$ Não se dava com a família da sua namorada ${ }_{\mathrm{A} 4}$

A valência, portanto, é susceptível de se classificar em duas modalidades: a primeira atesta um único tipo de construção no que diz respeito ao número e tipo de atantes, nunca se podendo registar mudanças nela; em tais casos, achamo-nos perante uma valência invariável de verbos como carecer, depender ou telefonar. A segunda tipologia, contrastivamente, permite que se possam constatar alterações tanto no número quanto no tipo de elementos atanciais de predicados qual casar, dizer, dar ou falar; corresponde esta segunda à valência variável. Na realidade, a modificação do marco predicativo dos verbos acha-se muito vinculada ao amplo conceito da transitividade, uma noção que igualmente se perfila como variável na dimensão contextual, geográfica, diacrónica, etc. ${ }^{18}$

A este respeito, vai ser a valência variável o ponto de partida necessário de forma a combinarmos a GV com a pesquisa de dialetalismos sintáticos. Assim, à pergunta de como desenvolvermos análises dialetológicas desde tal corrente teórica, é possível respondermos com, quando menos, as seguintes respostas: em primeiro lugar, desde a comprovação de como se modifica, se for o caso, o quadro atancial de cada verbo, isto é, se mudar o número de atantes de que precisa ao longo e largo do território numa visão geolinguística, em diferentes

17 Não tivemos cá em conta, para dar, as colocações, fraseologias e provérbios em que aparece, em que os traços da sua transitividade podem ver-se notoriamente modificados e, subsequentemente, também os seus conteúdos semânticos. Por outro lado, a complexidade semântica deste verbo, sem dúvida um dos mais usados no âmbito galego-português (daí, em parte, essa grande esefera de significados), verifica-se com só consultarmos as aceções com que figura no Dicionario da Real Academia Galega (acessível em https://academia.gal/dicionario/-/termo/busca/dar), no Dicionario de Dicionarios (disponível em http://sli.uvigo.es/DdD/ddd_pescuda.php?lang=gl\&pescuda=dar\&tipo_ busca=lema) ou no Dicionário Priberam da Língua Portuguesa (acessível em https://dicionario.priberam.org/dar). E essa grande amplitude significativa parece possuir um equivalente na também complexidade de dar do ponto de vista morfemático: é, junto com estar, o único verbo irregular da primeira conjugação e apresenta nos falares galegos uma notória variação tanto dialetal quanto socialmente, sobretudo no pretérito simples do indicativo e nos tempos com o tema de pretérito: eu dei $\sim$ din, ti deches $\sim$ diches, el/ela deu $\sim$ dou $\sim$ diu, eles/elas deron $\sim$ diron, etc.

$18 \mathrm{Na}$ verdade, o eixo temporal é um dos que mais facilita podermos verificar como se modificou o quadro atancial dos verbos. Neste sentido, acontece com muita frequência que estes, com o andar do tempo, selecionam diversas preposições, algumas das quais conseguiram manter-se na linguagem corrente até aos nossos dias e outras, contrastivamente, foram deslocadas para a obsolescência. Nos Miragres de Santiago, obra redigida entre finais do século XIV e princípios da seguinte centúria, ocorrem mostras como cuidar de (Esto coydaua eu de fazer, MS 202; etc.) ao lado de cuidar em (coydey en mãefestar os meus pecados, MS 198; etc.), escapar a (et por escapar a aquela pestilençia, MS 180), perguntar de (Por que me pregũtades do fillo de Deus, MS 24; Yde et pregũtade de todo coraçõ de aquel neno, MS 217; etc.) e perguntar por (Ese por que tu pregũtas era meu Deus, MS 53; etc.), provar de (prouou de a abrir, MS 63; etc.), subir em (sobio logo ẽno lugar, MS 23; etc.) junto a subir a (sobio aos çeos, MS 23, 26; soberia aos çeos, MS 51; etc.), etc. Igualmente, tornam-se de interesse as exemplicações e comentários que figuram nalgumas gramáticas históricas clássicas do português, como Ali (1964: 164-176) ou Dias (1954: 111 157), em que se sublinham estas caraterísticas sintáticas. 
situações comunicativas numa perspetiva contextual, etc. Em segundo lugar, com a verificação de como muda o tipo de elementos atanciais, ou seja, a manter-se a mesma organização valencial quanto ao número de atantes mas modificando a modalidade de algum deles. E em terceiro lugar, a partir da constatação de como se alteram as caraterísticas sémicas dos elementos atanciais, sem se modificar, porém, o marco predicativo do verbo.

Por outro lado, existe mais uma razão de peso para enveredarmos um caminho de confluência entre a GV e a sintaxe dialetal, como é o caráter inovador desse achegamento. Com efeito, as obras, clássicas ou recentes, em que se contém algum tipo de informação sobre fenómenos sintáticos locais, limitam-se, na maior parte dos casos, a desenvolver assuntos relacionados com a ordem de palavras e com certas construções mais ou menos fixadas, mas não abundam as perspetivas que combinem o potencial semântico das unidades lexicais com as suas caraterísticas e consequências sintáticas. A isto convém adicionarmos, ainda, que em ocasiões a fronteira entre aspetos morfológicos e sintáticos não está definida com clareza, nomeadamente nas obras de há uns anos, nas quais uma abordagem desde a morfologia para determinados assuntos dialetais também poderia ter um fácil encaixamento. Vasconcellos (1928, 1985, 1987), por exemplo, em finais do século XIX e durante o primeiro quartel da centúria seguinte, deu conta em reiteradas ocasiões da existência em falares setentrionais como traço sintático do clítico de dativo de segunda pessoa che (port. com. te), do uso do pronome sujeito vós igualmente em regiões nortenhas (port. com. vocês), da atestação da falta de mesóclise nos futuros simples do indicativo direi-te (port. com. dir-te-ei), do emprego da preposição $a$ para "indicar sítios" como à Quinta das Pinas (port. com. na Quinta das Pinas), da utilização do verbo haver a concordar com o complemento direto em construções do tipo haviam muitas pessoas (port. com. havia muitas pessoas), do uso de frases como ir d'a cabalo ou ir d'a pé (port. com. ir a cavalo, ir a pé), da documentação do advérbio interrogativo $u$ (port. com. onde é que está?), da deteção de advérbios apresentativos tipo vela lá (port. com. eis), da construção transitiva ir em (port. com. estar em), da locução a q'and'a ele e a canda mim (port. com. onde ele e quando eu), etc.

Por seu turno, a importante proposta de Segura (2013), atualizada com a nossa época e elaborada de uma forma mais sistemática, recolhe o fenómeno da interpolação pronominal em casos como Já lhe eu aqui disse que não ias vir, etc. (port. com. Eu já lhe disse aquí que não ias vir), a conservação de vós nos dialetos setentrionais, o uso do pretérito mais-que-perfeito simples cantara (port. com. tinha cantado), a atestação de gerúndios flexionados em falares centro-meridionais cantândomos, cantândodes, etc. (port. com. cantando), a manutenção do gerúndio em complexos verbais perifrásticos em dialetos centro-meridionais do tipo estar cantando (port. com. estar a cantar), etc. ${ }^{19}$

Mas em nenhuma dessas transcendentes obras se operou com os traços sintáticos e semânticos de unidades lexicais de forma a realizar pesquisas em variação dialetal, umas por corresponderem a outras épocas e outras por adoptarem outros modelos de análise. Assim, relativamente a estas propostas de fenómenos dialetais, achamos que a GV pode significar mais um passo na análise de características sintáticas locais ao ultrapassar a porta da transitividade e do marco predicativo dos verbos, não ficando somente na atestação de ordens de elementos frásicos e clausulares ou no levantamento de estruturas fixadas pelo uso.

19 Torna-se necessário notarmos o facto de muitos destes fenómenos dialetais dos falares portugueses recolhidos por Vasconcellos ou por Segura fazerem parte na atualidade da variedade padrão do galego ou, quando menos, de serem usualíssimos na linguagem literária contemporânea. Nalguns casos, a sua vigência na Galiza não ficou desapercebida ao ouvido de José Leite de Vasconcellos, que, ciente dessa identificação entre os falares de ambas as margens do rio Minho, se manifestou com uma relativa frequência a assinalar esta circunstância. $\mathrm{O}$ advérbio $u$, por exemplo, inspirou-o no sentido seguinte numa aclaração: "Ulo, junto a outra palavra, em interrogação (por "onde está"). Ulo usa-se na Barbeita (Monção), no Norte de Trás-os-Montes, e em galego" (Vasconcellos 1928: 19). Ao mesmo tempo, a atestação da maior parte destes traços linguísticos em textos de proveniência tradicional também se não torna estranha e pode-se afirmar ao respeito que os mais possuem uma viçosa documentação: Rapazes, vos vou contar casos da minha mocidade (RPT, I 226); -De três vacadas que tenho darei-te qual tu quiseres (RPT, I 193); meterás-me no convento, da qual da Santa Maria; / darás-me a comer por hora e a beber por medida (RPT, I 250); -Quanto davas mais ó Helena, a quem to aqui trouxera? / -Três moedas que eu tinha, todas três t'eu dera (RPT, I 192); Mostra-me cá tua metade, pois a minha vê-la aqui (RPT, I 207); Das onze para a meia-noite, quando o rei esteja dormindo (RPT, I 483); Juntara-se a povoação para prender o malvado (RPT, II 979); etc. 


\subsubsection{Modificação do número de atantes}

\section{a) Ampliação}

O primeiro caminho que vamos comentar é o que se atesta no território galego-português para o caso de verbos que, a terem um determinado número de elementos argumentais, são capazes de o modificarem. Neste sentido, já Busse e Vilela (1986: 67) indicaram que há "verbos que apresentam construções com um número variável de actantes", que podem reduzir-se ou ampliar-se a respeito do considerado mais corrente. Vejamos, neste sentido, alguns exemplos. Os marcos predicativos dos verbos climatológicos como chover, nevar, orvalhar, ventar, etc. informam de que se trata de verbos avalenciais ou avalentes, pois são impessoais e não precisam de qualquer atante, nem até do primeiro ou sujeito, para terem plena significação e coerência sintático-semântica. Porém, em registos de língua populares de algumas regiões, tais verbos não reprovam adicionar um elemento argumental, que em tais casos passa sempre a comportar-se como sujeito na forma fixada do pronome pessoal masculino ele, como assinalam Vilela e Koch (2001: 212) para o caso do português europeu, não aparecendo na variedade brasileira:

4. (a) Ele $_{\mathrm{A} !}$ choveu muito e agora estão as ruas inundadas

(b) Ele $e_{\mathrm{A} 1}$ nevou sem parar durante toda a noite

(c) E ele $_{\mathrm{A} 1}$ orvalha e com este orvalho não se pode sair

Ora bem, os verbos climatológicos avalenciais não são os únicos capazes de acrescentarem um pronome de terceira pessoa ele para conseguirem um aparente sujeito ou para gerarem uma frase nominal com tal função sintática. Muito relacionado com estes usos impessoais de ele está a utilização da mesma forma pronominal masculina singular como reforço interrogativo ou narrativo em determinadas construções, a qual também se documenta com relativa facilidade em registos coloquiais e em determinadas áreas do espaço linguístico galego-português.
Assim, os dados que figuram em ILG (1995: 188-189) localizam exemplos como El é certo...? ou El tendes...? em toda a Galiza, se bem que o seu predomínio se faz mais evidente na metade meridional do país.

Pela nossa experiência, temos a impressão de ambos estes usos de ele -o emprego junto a verbos impessoais e a utilização como reforço- corresponderem a um traço que tende, devagar, a ir desaparecendo da linguagem corrente $^{20}$. E que se trata de um fenómeno cada vez menos atestável nos atuais falares galego-portugueses parece ficar apoiado pelas suas referências nos textos especializados. Assim, enquanto nem trabalhos de caráter geral (cf. Segura 2013) o incluem na sua relação de traços diatópicos relevantes do português continental nem também outros estudos de índole mais local (cf. Simão 2011), diversas obras, em confronto, têm recolhido a sua vigência na língua oral popular de há décadas. Tal é o caso, novamente, de Vasconcellos (1987: 122), autor que, em 1901, indicava que "on remarque aussi l'emploi du pronom-sujet avec des verbs impersonnels: ele chove, ele são horas". A produtividade deste fenómeno no português setentrional faria com que algum tempo mais tarde voltasse a reparar neste traço:

É corrente juntar-se ele a uma frase, referido a tôda ela, como que para anunciar o que se vai dizer: "e ele num sei s'isso é berdade" [...], onde ele representa, quanto a mim, o pronome demonstrativo arcaico elo. (Vasconcellos 1928: 222)

$\mathrm{Na}$ linguagem familar, não só de Guimarães, mas de outras localidades, há muitos exemplos análogos: "ele os lobos andam com fome", "ele aqueles campos estão bem cultivados", "ele aquela mulher é muito bondosa". Em Aquilino Ribeiro, Terras do Demo, romance que reproduz admiravelmente a vida popular e o estilo da Beira, lê-se, pág. 161: “Ai! Ele as mulheres são ruim gado". (Ibid.: 222, nota 1 )

Mais um trabalho de algum tempo que documentou esta singularidade foi o de Buescu (1984: 115), obra que estuda o português popular da localidade beirã de Monsanto. Por seu turno, também Garcia (1979: 88) o teve

20 Não obstante esta regressão atual, teve um grande sucesso nalguns textos literários contemporâneos, sobretudo naquelas obras que se aproximaram conscientemente da língua oral popular e dialetal. Veja-se Freixeiro Mato (2013: 121-123), autor que proporciona um cumprido exemplário destes usos de ele (el no galego), ao passo que faz referencia a essa secundarização na oralidade atual: "Un caso particular constitúeno os usos especiais ou valores estilísticos de $e l$, consagrados na lingua literaria dalgúns dos nosos grande escritores, aínda que cada vez máis sentidos nalgún caso como arcaicos, propios da xente idosa ou simplemente literarios". 
em consideração no seu estudo do falar da Glória do Ribatejo, embora o detetasse em construções não exatamente equivalentes às antes assinaladas: "o pronome ele é usado enfaticamente na frase 'Esse é que valia a pena ele meter-se a cunv'rsar"”.

Mas a recorrência a um pronome pessoal tónico utilizado como sujeito não supõe a única hipótese existente na linguagem popular para esta fazer um $\mathrm{A}_{1}$ entrar em ação. Os verbos avalenciais são, com diferença, os menos representados na sintaxe das línguas preferencialmente transitivas e enformam um grupo de predicados bem pouco numeroso no conjunto total dos verbos. Daí que haja uma certa tendência de maneira a procurar-lhes um marco predicativo mais facilmente assimilável aos cadros atanciais gerais, mesmo que seja o mais simples. A este respeito, documentam-se exemplos de frases nominais lexicalmente realizadas que, através das regras de concordância morfemática estabelecidas entre o verbo e o sujeito, exigem que as tais frases sejam identificáveis com essa função sintática. Nesse sentido, são interessantes os exemplos e as reflexões que já proporcionava Amaral (1945: 252-256) no equador do século XX relativamente de verbos avalentes como chover ou trovejar, para os quais acrescenta até exemplos literários provenientes de Camões, Vieira, Gonçalves Crespo ou Antero de Figueiredo. Nas suas mostras corrobora-se como tais verbos, quando acrescentam um atante, obrigam-no sempre a incorporar-se nas listagens do sujeito ou $A_{1}$, conforme se observa nos casos que se seguem, tirados de Amaral:
5. (a) Choveu muita água $a_{\mathrm{A} 1}$
(b) Chovem abundantes chuvas ${ }_{\mathrm{A} 1}$
(c) Choveram raios e coriscos ${ }_{\mathrm{A} 1}$
(d) Trovejaram impropérios ${ }_{\mathrm{A} 1}$

Na realidade, a origem deste tipo de construções com verbos avalentes não é contemporânea, mas goza de séculos de existência na língua, já se atestando no galego-português medieval, segundo se pôde constatar em López Leizán (1999). O autor, depois de analisar um córpus de obras escritas na altura, conclui a indicar que na língua antiga "aínda se lles trataba de dar unha orixe a este tipo de fenómenos tentando buscarlles un axente creador"; com o passar do tempo, nas suas palavras, a tal possibilidade começou-se a "considerar redundante e innecesaria" (Ibid.: 121). Alguns dos exemplos que expõe são os que se seguem:

6. (a) et cõmo chouẽ as nu(u)es

(b) ca nõ chouera Deus

(c) foy Deus cõtra elles moy sanudo, et choueo sobre elles

(d) enque el esto mandaua, // trageria odeluvio et choveria sobrela terra

\section{b) Redução}

Um outro caso que ilustra este primeiro tipo de pesquisa dialetológica que afeta o número de atantes é precisamente aquele contrário ao anterior, mercê aos verbos valenciais capazes de reduzirem a sua cifra de argumentos, situação que, não sendo comum, conhece decerto alguma significativa e interessante mostra. Comentemos, portanto, alguma delas. O verbo guardar apresenta na linguaem corrente como quadros atanciais, entre outros, estruturas do tipo $\mathrm{V}+\mathrm{A}_{1}+\mathrm{A}_{2}\left(+\mathrm{A}_{5}\right)(7 \mathrm{a}-7 \mathrm{~b})$ ou $\mathrm{V}+\mathrm{A}_{1}+$ $\mathrm{A}_{2}+\mathrm{A}_{4}$ com construçãoo pronominal $(7 \mathrm{c}-7 \mathrm{~d})$, segundo se vê nos seguintes exemplos:

7. (a) Os líderes sindicais ${ }_{\mathrm{A} 1}$ guardaram para si as opiniões ${ }_{\mathrm{A} 2}$ sobre a greve geral

(b) Após a reunião, a ministra ${ }_{\mathrm{A} 1}$ guardou na pasta ${ }_{\mathrm{A} 5}$ a proposta de decreto ${ }_{\mathrm{A} 2}$

(c) $\left[T u_{\mathrm{A} 1}\right]$ Guarda-te $e_{\mathrm{A} 2}$ bem dessas falsas amizades $_{\mathrm{A} 4}$

(d) Depois do conflito, o professor de retórica $_{\mathrm{A} 1}$ guardou-se ${ }_{\mathrm{A} 2}$ de aparecer na faculdade $_{\mathrm{A} 4}$

No entanto, em certas zonas, este verbo é capaz de ver reduzido o seu quadro atancial. Assim, em falares da região de Bergantinhos, guardar ou gardar pode aparecer empregado somente com o sujeito. Em tais circunstâncias, nota-se uma relevante modificação do seu significado, que passa a ser equivalente a conservar ou manter $^{21}$. Esta utilização aparece com frequência associada a determinados produtos

21 As primeiras atestações de gardar com este valor de 'conservar' são as registadas por Leandro Carré Alvarellos em finais da década de 20 do passado século e nos seguintes anos 30. A partir de aqui, outros lexicógrafos, como Eladio Rodríguez González ou José Ibáñez López, parece terem recolhido essa aceção para a incorpoarem às suas obras, de acordo com o Dicionario de Dicionarios (accesível em http://sli.uvigo.es/DdD/ddd_pescuda. php?lang=gl\&pescuda=gardar\&tipo_busca=lema). 
agrícolas, como as batatas, denominadas normalmente patacas na Galiza mas também castañas ou mesmo castañas da terra no galego dessa comarca bergantinhã. Nós pudemos registá-lo em exemplos como estes:

8. (a) Neste ano as patacas $_{\mathrm{A1}}$ non gardaron [= não se conservaram]

(b) Non me estraña que, con este frío, as castañas $_{\mathrm{A} 1}$ non garden [= não se conservem]

Mais um outro exemplo ao respeito de um predicado verbal que participa da míngua no número de atantes é ousar. Na linguagem normal, corresponde a um verbo transitivo, de caráter causativo, e possui conteúdos semânticos bastante equivalentes aos de atrever-se $a$, segundo se percebe nas seguintes mostras:

9. (a) Ousou aparecer na festa totalmente ébrio e insultando as autoridades

(b) Não ouses dirigir-te a mim dessa forma!

(c) Durante o velório, ousou ofender a família do defunto

Contudo, em determinadas áreas do território galego, como é o caso de algumas zonas da Terra Chá, ousar pode aparecer com uma estrutura monovalente com o sujeito ou $\mathrm{A}_{1}$, em cujo caso equivale a não ter medo ${ }^{22}$ :

10. (a) Ousamos e imos dar unha volta polo campo

(b) Ousas ou non ousas?

(c) Non vou saír: vin uns lobos e non ouso

\subsubsection{Modificação da tipologia dos atantes}

O segundo tipo de análises dialetológicas que encaixam harmonicamente com o marco teórico da GV são, conforme dissemos, as diferenças que se atestam geograficamente na estruturação atancial dos verbos. Neste âmbito, umas das mais sobressalentes é aquela que se verifica ao compararmos algumas regências entre o galego, o português europeu e o português americano. A este respeito, Vilela (2002: 326-327), a falar de como interagir no ensino com a norma europeia e americana da língua, sublinhou determinadas "divergências" que estão "a definir-se"; essas diferenças detetam-se, entre outros campos, nas regências do âmbito verbal entre ambas as modalidades de português, nas quais aparecem, às vezes, modificações no tipo de atantes protagonizadas por $\mathrm{A}_{2}$ com a co-ocorrência de outros atantes, conforme ilustram algumas mostras de (11) e (12) expostas por Vilela:
11. (a) assistir (PE) / assistir a (PB)
(b) agradar / agradar a (PB)
(c) precisar de (PE) / precisar (PB)
(d) necessitar de (PE) necessitar (PB) ${ }^{23}$
(e) namorar $(\mathrm{PE}) /$ namorar com $(\mathrm{PB})$

Em ocasiões, a única diferença assenta no tipo de preposição que introduz o elemento atancial:
12. (a) contribuir para (PE) / contribuir com (PB)
(b) brincar $a(\mathrm{PE}) /$ brincar de $(\mathrm{PB})$

A nos centrarmos nos falares galegos e portugueses, uma desas hipóteses de regências verbais é a que temos no caso de esquecer, predicado para o qual, na atualidade, existem diversas posibilidades de construção argumental na oralidade galega:
13. (a) $A$ Xoana $a_{\mathrm{A} 1}$ esqueceu $o$ libro $_{\mathrm{A} 2}$
(b) A Xoana ${ }_{\mathrm{A} 1}$ esqueceuse do libro ${ }_{\mathrm{A} 4}$
(c) $A$ Xoana ${ }_{\mathrm{A} 3}$ esqueceulle $o$ libro $_{\mathrm{A} 1}$
(d) $A$ Xoana ${ }_{\mathrm{A} 3}$ esquecéuselle $o$ libro $_{\mathrm{A} 1}$
(e) $* A$ Xoana $_{\mathrm{A} 1}$ esqueceuse $o$ libro $_{\mathrm{A} 2}$

22 A sua documentação já figura em repertórios lexicais do século XIX, desde os quais se projetou numa considerável parte dos trabalhos lexicográficos modernos. Vejam-se, neste sentido, as referências bibliográficas que figuram no Dicionario de Dicionarios (disponível em http://sli.uvigo.es/DdD/ddd_pescuda.php?lang=gl\&pescuda =ousar\&tipo busca=lema).

23 Veja-se o exposto em Peres e Móia (1995: 113) relativamente aos verbos precisar e necessitar, trabalho em que se não faz qualquer referência às tendências do português americano ou europeu: "É ainda interessante referir o caso dos verbos precisar e necessitar, predicados que admitem tanto complementos preposicionados com de como complementos no preposicionados. Apesar de a presença da preposição ser opcional, parece-nos que actualmente as formas preposicionadas são bastante mais frequentes, quando os complementos em causa são nominais ou oracionais infinitivos". 
Comvém remarcarmos que, de acordo com o exposto em trabalhos atuais (cf. ILG 1995: 214-215), todas elas estão presentes ao longo e largo do país (e nós acrescentaríamos também no galego literário), embora com diferentes proporções. Em harmonia com esses trabalhos, uma construção como a de (13a) parece ser comum a todo o território e conhece uma maior documentação na província de Ourense, não se registando nos falares pontevedreses. Por sua vez, o exemplo (13b) passa por ser um dos mais minoritários ao só se atestar em três pontos dos falares centro-orientais. A estrutura (13c) também não é das mais facilmente documentadas, posto que se possa achar em vários pontos da metade meridional da Galiza. Já a construção (13d) emerge sem qualquer tipo de dúvida como a melhor representada, nomeadamente na metada oriental do país, o que pode ver-se ajudado pela existência de estruturações análogas em espanhol com o verbo olvidar. Finalmente, não está sem exemplo uma fórmula do tipo (13e), se bem que seja a que apresente as mostras mais fracas; nesta estrutura aprecia-se uma construção pronominal reflexa indireta, o que a faz ser a mais suspeitosamante coincidente com o castelhano e considerada inexistente ou agramatical no português corrente contemporâneo (cf. Peres e Moia 1995: 112-113). Torna-se interessante ponderarmos aqui que as diferenças semânticas entre os exempos de (13) são mínimas (não assim as sintáticas ou as informativas) ${ }^{26}$.

No caso das falas galegas, como se viu, as diferentes possibilidades de construção com esquecer aparecem por toda a parte, muito embora haja tendências que ilustram que algumas são mais comuns em determinadas regiões e outras aparecem com maior facilidade em áreas diferentes. Se fóssemos aos falares portugueses, observaríamos que acontece qualquer coisa similar, pois, talvez sendo a mais identificável pelo padrão a estrutura esquecer-se de, análogas construções a algumas de (13) também se documentam no território. Os seguintes exemplos provém da literatura tradicional do distrito transmontano de Bragança e pertencem às vezes, como se pode deduzir, a diversas recitações de um mesmo texto:

14. (a) lá no meio do caminho esqueceu-se-me a guilhada (RPT, I 335)

(b) lá no meio do caminho esqueceu-me a guilhada (RPT, I 335)

(c) Volta atrás, ó pastorinho, que t'esque ceu ũa ovelha (RPT, I 405)

(d) Que m'esqueceu minha espada na fonte donde bebía (RPT, I 750)

(e) lá no meio do caminho esqueci-me da guilhada (RPT, I 336)

Estruturas parecidas são as que se documentam com os verbos acordar e lembrar ${ }^{27}$, antónimos de esquecer, que conhecem várias das possibilidades atanciais de esquecer, ainda que por enquanto não tenhamos dados precisos de adscrição territorial ou contextual ${ }^{28}$ :

15. (a) A Saleta ${ }_{\mathrm{A} 1}$ acordou aquela poesia

(b) A Saleta $_{\mathrm{A} 1}$ acordou-se daquela poesia $_{\mathrm{A} 4}$

(c) À Saleta ${ }_{\mathrm{A} 3}$ acordou-lhe aquela poesia $_{\mathrm{A} 1}$

(d) À Saleta ${ }_{\mathrm{A} 3}$ acordou-se-lhe aquela poesia $_{\mathrm{A} 1}$

16. (a) A Saleta $_{\mathrm{A} 1}$ lembrou aquela poesia ${ }_{\mathrm{A} 2}$

(b) A Saleta $_{\mathrm{A} 1}$ lembrou-se daquela poesia $_{\mathrm{A} 4}$

(c) À Saleta ${ }_{\mathrm{A} 3}$ lembrou-lhe aquela poesia $_{\mathrm{A} 1}$

(d) À Saleta ${ }_{\mathrm{A} 3}$ lembrou-se-lhe aquela poesia $_{\mathrm{A} 1}$

24 Manifesta a este propósito Silva-Corvalán (1989: 98) que a “variación sintáctica plantea el problema de las posibles diferencias de significado que pueden estar asociadas con las variantes. Es decir, mientras las variantes fonológicas constituyen dos o más formas 'de decir la misma cosa', las variantes de una variable sintáctica no son claramente dos o más formas diferentes de decir lo mismo".

25 Para as esferas semânticas de ambos os verbos e os matizes e diferenças no plano do significado que apresentam tanto cada um deles como um a respeito do outro, cf. o Dicionario da Real Academia Galega (disponível em https:// academia.gal/dicionario/-/termo/busca/acordar), o Dicionario de Dicionarios (http://sli.uvigo.es/DdD/ddd_pescuda.php?lang=gl\&pescuda=acordar\&tipo_busca=lema) e o Dicionário Priberam da Língua Portuguesa (acessível em https://dicionario.priberam.org/acordar).

26 Veja-se, a este respeito, o parecer de Peres e Móia (1995: 116), em que se salienta que convém "ter presente que as formas verbais recordar, lembrar e esquecer podem corresponder a pelo menos dois predicados distintos. Um destes predicados [...] vem sempre associado a uma forma pronominal intrínseca, variável em pessoa e número, pelo que deveria ser identificado como, respectivamente, recordar-se, lembrar-se e esquecer-se. O outro predicado é o que podemos identificar pela simples forma verbal, sem elemento pronominal". 
Por outro lado, existem no espaço galego-português construções transitivas em que se verifica a alternância $\mathrm{V}+\mathrm{A}_{1}+\mathrm{A}_{2} \operatorname{com} \mathrm{V}+\mathrm{A}_{1}+\mathrm{A}_{4}$ em predicados verbais como comer, malhar, roer, sachar, segar, etc., as quais têm conhecido na literatura especializada uma interessante nómina de possíveis denominações e inspirado alguns estudos monográficos ${ }^{27}$. Para além de outras partículas nexuais, a mais recorrente neste tipo de construções é $\mathrm{em}$. Repare-se nalguns exemplos atuais:
17. (a) O teu amigo $_{\mathrm{A} 1}$ comia $o$ pão $o_{\mathrm{A} 2} \mathrm{com}$
(b) O teu amigo Al $_{\text {comia no pão }}$ com muita fome
(c) $\left[\right.$ Elas $\left._{\mathrm{A} 1}\right]$ Estavam a segar a erva ${ }_{\mathrm{A} 2}$ quando começou a chover
(d) $\left[\right.$ Elas $\left._{\mathrm{A} 1}\right]$ Estavam a segar na erva $a_{\mathrm{A} 4}$ quando começou a chover

Mas a estrutura, apesar de já no século XIX figurar comentada nalguma gramática (cf. Saco Arce 1868: 186-188), parece retrotrair as suas origens a tempos mais longínquos, como a Baixa Idade Média, a teor de mostras como a seguinte, proveniente dos Miragres de Santiago (cf. Sánchez Rei 2010: 83):

18. Ẽno ãno da Encarnaçõ de Nostro Señor, de mĩll et çento et dous ãnos, hũu bispo viindo da casa santa de Iherusalem en hũa naue, seendo cabo do boordo leendo en hũu liuro, vẽo hũa moy grãde onda e lan çoo ẽno mar cõ outros que y andauã (MS 186).

De uma perspetiva atual, muito embora se não possam marcar áreas em que se atestam de preferência as possibilidades de (17b) e (17d), não estão isentas de serem percebidas como estruturas sintáticas dialetais facilmente analisáveis desde a GV, sobretudo se tivermos presente alguns traços que dizem respeito à sua caraterização. Em primeiro lugar, do ponto de vista geográfico, parece registarem-se por toda a parte quando menos na Galiza, ainda que com maior frequência em variedades rurais que em falares urbanos; daí que Buescu (1984: 116) as pudesse encontrar em dialetos da Beira e as comentasse salientando que se tratava de "uma tendência analítica muito marcada" relativamente à linguagem normal. Em segundo lugar, contando com o fator registo, ouvem-se melhor em variedades coloquiais e populares que em contextos formais, isto é, a sua atestação vai ver-se favorecida por uma maior informalidade no uso da lingua. E em terceiro lugar, caso pensássemos na variável idade, aparecem mais frequentemente em faixas etárias altas do que baixas, quando menos segundo a nossa paticular experiência.

Por último, deixando de parte a sua adscrição a variedades muito concretas, o uso de uma ou de outra estrutura pode estar condicionado pela expressão de determinados matizes que, sem modificarem no essencial o significado do verbo, formulam com efeito algum tipo de subtil diferenciação. Assim, para Lapa (1984: 269), um exemplo proveniente da "linguagem popular" como Comia no presunto como um danado inspirou-o a escrever que a preposição em "exprime também aqui o alvoroço, o pressuroso interesse dedicado ao acto"; e, por seu turno, harmonizando de alguma forma com o indicado pelo humanista de Anadia, neste tipo de estruturas, para Freixeiro Mato (2013: 358), tem de se ponderar um "valor enfático con claras repercusións estilístico-expresivas". Considerações à parte no âmbito da inegável maior expressividade que exprimem os complementos desta natureza introduzidos por preposição, o certo é que se permitem entrever algumas pequenas diferenças de conteúdos de se empregar $\mathrm{A}_{2}$ ou $\mathrm{A}_{4}$, conforme ilustram (19a) e (19b) e (19c) e (19d):

19. (a) Comeu no caldo e depois adormeceu [não se sabe se concluiu o caldo]

(b) Comeu o caldo e depois adormeceu [pode pensar-se que acabou o caldo]

(c) Tirou as chaves no chão [implica menor determinação na ação]

(d) Tirou com as chaves ao chão [pressupõe maior determinação na ação]

27 Têm-se, com efeito, utilizado nomes como 'complemento direto com preposição', 'complemento preposicional', 'suplemento', 'complemento indireto', complemento de régime indireto', 'complemento circunstancial com valor terminativo', etc. (cf. Sánchdez Rei 2010: 69-75). Quanto ao seu tratamento, nem sempre necessariamente coincidente, destaca o desenvolvido nas modernas gramáticas académicas do galego (cf. Álvarez e Xove 2002: 98-100, 102-105; Freixeiro Mato 2006: II, 639-645), bem como o que mereceu em determinados monográficos (cf. Rodríguez Guerra 1997; Sánchez Rei 2010). 


\subsubsection{Modificação das caraterísticas sémi- cas dos atantes}

Finalmente, o terceiro tipo de pesquisa dialetal no âmbito da teoría da valência que foi apresentado mais acima partia dos traços sémicos dos atantes e das alterações que se detetam neles. Para exemplificarmos tais mudanças, vamos acudir, em primeiro lugar, a acontecer. Normalmente, as clásulas em que ele figura projetam-se a partir de uma estrutura monovalente $V+A_{1}$ como em (20a-20b) ou de uma bivalente $\mathrm{V}+\mathrm{A}_{1}+\mathrm{A}_{3}$ segundo se vê em (20c20d), em cujos casos se situa semanticamente na órbita de acaecer, ocorrer ou suceder:

20. (a) Aconteceu que choveu sem parar ${ }_{\mathrm{A} 1}$

(b) Acontece agora que não queremos ir de férias ${ }_{\mathrm{A} 1}$

(c) Aconteceu-lhes ${ }_{\mathrm{A} 3}$ tudo o que era de esperar $_{\mathrm{A} 1}$

(d) Aconteceu-nos ${ }_{\mathrm{A} 3}$ uma coisa dificil de contar $_{\mathrm{A} 1}$

Segundo se pode observar, a idiossincrasia sémica do sujeito das mostras de (20) caraterizase pelo traço [-inanimado]. Porém, não se desconhecem utilizações em que $\mathrm{A}_{1}$ se emprega com o traço [+animado] ou até [+humano], possibilidades que fazem com que o verbo modifique substancialmente o seu significado e que adopte uns valores muito próximos de enlouquecer, tolejar ou virar tolo/a. Tais aceções são totalmente minoritárias a respeito das mais comuns de (20) e, não obstante possam detetar-se em mais regiões, nós temo-las registado em falares ourensanos meridionais ${ }^{28}$ :

21. (a) Os animais da casa ${ }_{\mathrm{A} 1}$ aconteceram por causa da fome

(b) Nunca the viram nada, mas a $_{\text {cadela }}$ aconteceu e começou a morder as crianças

(c) O seu pai ${ }_{\mathrm{Al}}$, depois de tanto sofrimento durante a vida, acabou por acontecer
O segundo dos predicados verbais que vamos utilizar como exemplo é meter. Este verbo trivalente, com uma esfera semântica muito próxima de introduzir, conhece, junto a outras possíveis ${ }^{29}$, a construção máis habitual com $\mathrm{A}_{1}$, $\mathrm{A}_{2}$ e $\mathrm{A}_{5}$ em casos como os de (22a, 22b e 22c), em que $\mathrm{A}_{5}$ possui certas caraterísticas sintático-semânticas, pois não se pode introduzir ou meter nada que não seja no interior de qualquer coisa:

22. (a) A Maria $_{\mathrm{A} 1}$ meteu o livro ${ }_{\mathrm{A} 2}$ na caixa branca $_{\mathrm{A} 5}$

(b) Com essa atitude, o Luís $_{\mathrm{A1}}$ vai meter as amizades ${ }_{\mathrm{A} 2}$ num problema sério ${ }_{\mathrm{A} 5}$

(c) Não sei se $t u_{\mathrm{A} 1}$ tinhas metido $o$ iogurte $_{\mathrm{A} 2}$ no frigorifico $_{\mathrm{A} 5}$

Mas no marco da regência que protagoniza o verbo sobre os seus elementos atanciais, sobranceiam as estruturas seguintes, detetadas por nós nalgumas falas do extremo ocidental da atual provincia da Corunha, em que $\mathrm{A}_{5}$ parece exibir precisamente os valores contrários aos exemplos citados em (22):
23. (a) Ao sair de casa, $\left[e u_{\mathrm{A} 1}\right]$ metia $o$ caldeiro $_{\mathrm{A} 2}$ fora $_{\mathrm{A} 5}$
(b) A sua tia ${ }_{\mathrm{A} 2}$ metia fora ${ }_{\mathrm{A} 5}$ todos os medos $_{\mathrm{A} 2}$
(c) Depois de $\left[\right.$ nós $\left.s_{\mathrm{A} 1}\right]$ metermos os animais $_{\mathrm{A} 2}$ fora $_{\mathrm{A} 5}$, fomos descansar um
pouco

Note-se que nestas mostras meter, por causa dos traços semânticos de $\mathrm{A}_{5}$, adquire uma esfera significativa mais ampla, próxima do verbo $p \hat{r}$. Daí que, com todas as cautelas necessárias, a origem desas construções esteja muito relacionada com a existência de estruturas equivalentes às deste verbo, as quais apresentam um caráter mais comum na oralidade galega atual que as atestadas para meter. De facto, usando em lugar de meter o verbo pôr, a construção torna-se totalmente corrente no galego e perde a exclusividade geográfica dessa região da Corunha:

28 Dentro do pouco usuais de todas estas estruturas, outras parecem contrastivamente ser menos infrequentes, como estar acontecido/a, ficar acontecido/a, parecer acontecido/a, etc. Também aparecem estes valores de acontecer em construções causativas ou hiper-transtivas, do tipo A fame fixo acontecer os animais, A sede fai acontecer os cans, etc.

29 Em registos coloquiais, meter no galego também pode equivaler a dar ou proporcionar (cf. Meteulle un grolo; Meteulle unha patada; etc.), fazer-se (cf. Meteuse a banqueira; Metémonos a músicos; etc.), infundir (cf. Sempre que podía, metíalles medo; Meteuche un bo susto; etc.), ofender (cf. Meteuse co teu compañeiro; Non te metas comigo; etc.), etc. Veja-se, neste sentido, a informação recolhida no Dicionario da Real Academia Galega (disponível em https://academia.gal/dicionario/-/termo/busca/meter) ou no Dicionario de Dicionarios (accesível em http://sli. uvigo.es/DdD/ddd_pescuda.php?lang=gl\&pescuda=meter\&tipo_busca=lema). 
24. (a) Ao sair de casa, $\left[e u_{\mathrm{Al}}\right]$ punha $o$ caldeiro $_{\mathrm{A} 2}$ fóra $_{\mathrm{A} 5}$

(b) A sua tia ${ }_{\mathrm{A} 2}$ punha for ${ }_{\mathrm{A} 5}$ todos os medos $_{\mathrm{A} 2}$

(c) Depois de $\left[n o ́ s_{\mathrm{A} 1}\right]$ pormos os animais $_{\mathrm{A} 2}$ fora $_{\mathrm{A} 5}$, fomos descansar um pouco

Certamente, não correspondem a um fenómeno muito habitual na sintaxe dialetal galegoportuguesa ambos estes casos de acontecer ou meter. Contudo, a lateralizarmos a adscrição geográfica e priorizando outros fatores de variação, como o contextual ou o estratual, pode documentar-se em mais verbos. Quiçá um dos mais ilustrativos seja bater, que apresenta diferentes esquemas atanciais (veja-se 2.3.2), entre os quais, sem qualquer ânimo de exaustividade, sobranceiam os seguintes:

25. (a) Os autocarros bateram por causa do nevoeiro

(b) Lembro que sempre bateram, nunca se deram bem

(c) As pombas, feridas, não podiam bater as asas

(d) A janela está tão mal feita que ao abrir bate no teto

(e) Para fazeres uma boa omeleta tens de bater com paciência um par de ovos

(f) Batia nos ovos com muita rapidez

(g) Era uma pessoa muito agressiva e batia nos filhos com frequência

(h) Era uma pessoa muito agressiva e batia-lhes com frequência

(i) Caminhando pela serra, bateu com o lobo

(j) Por um descuido, bateu na mesa com a perna e agora tem uma ferida

Em casos como estes, torna-se fácil verificarmos uma grande alteração semântica, vinculada, conforme dissemos anteriormente, à valência variável (veja-se 2.3). Mas, para os nossos interesses, reparemos apenas nalgumas construções. Assim, com o sema [+humano] de $(25 \mathrm{~g})$ constata-se com facilidade a grande diferença no significado a respeito de atantes que também vão introduzidos pela mesma preposição em (25d, 25f, 25j), embora aqui nada tenha a ver com o de 'dar pancadas' de (25g). E o mesmo traço sémico [+humano] faz com que em (25h) bater também adquira idêntico ou parecido significado que o de $(25 \mathrm{~g})$.
Em resumo, os vinte e cinco exemplários que foram citados até aqui serviram para verificarem que a GV permite o estudo da variação sintática dialetal. Para esta finalidade, tem necessariamente de se partir das caraterísticas do quadro atancial dos verbos e dos traços sintático-semânticos deles, a se centrar assim no tipo de valência denominado variável.

\section{Conclusões}

Desde os mais antigos textos conservados, alguns deles datados vários séculos antes da nossa era, já se tem constância da existência da variação linguística. Porém, a disciplina que se ocupou de estudar como se modificavam as línguas inicialmente no eixo geográfico não apareceria até aos anos finais do século XIX, muito ligada ao ambiente cultural e científico da altura. Esse saber, a dialetologia, encarregou-se num princípio da análise de variedades rurais, já que se acreditava que no mundo camponês se conservavam mais puras as essências das línguas. Com esses objetivos, dedicou a maior parte das suas pesquisas a fenómenos fonéticos, morfológicos e vocabulares, de modo que outras disciplinas, como a sintaxe, foram lateralizadas em tais investigações. Isto trouxe consigo que, ainda na atualidade, se disponha de uma notória quantidade de informação referida á variação fonética ou vocabular de muitas línguas, mas que, em confronto, o que se sabe das variantes sintáticas dialetais seja proporcionalmente bem mais escasso.

O estudo da dialetologia também se viu secundarizado ou propositadamente esquecido desde importantes correntes de pensamento científico, como as estruturalistas e as formalistas, as quais só repararam em que com certeza era factível desenvolverem essas pesquisas a partir da segunda metade do século XX. No entanto, essas aproximações centraram-se preferencialmente em aspetos fonéticos e fonológicos, daí que a sintaxe, mais numa ocasião, se visse afetada e, ao passo, que o volume de literatura especializada capaz de fazer amalgamar conceitos como variação sintática, dialetologia e estruturalismo ou formalismo se não caracterizasse por uma grande produção.

Hoje, conforme figura em obras modernas, concede-se atenção a fenómenos dialetais de natureza sintática e podem-se felizmente assinalar algumas tendências quanto à maior ou menor facilidade de atestação de traços linguísticos em determinadas regiões do espaço galego-português. Essas caraterísticas, no 
entanto, referem mormente ordens de palavras (como a interpolação, por exemplo) ou recolhem elementos de análise que também poderiam encaixar sem muita dificuldade em epígrafes dedicadas à morfologia ou, quando menos, à morfossintaxe (manutenção do pronome vós, deteção de variantes na conjugação verbal como cantara ao lado de tinha cantado, estar + gerúndio ao lado de estar a + infinitivo, documentação do gerúndio flexionado, etc.).

Por isso, a GV, uma das escolas linguísticas máis notáveis do século XX, pode, a nosso ver, formular novas possibilidades de pesquisa dialetal. A GV assenta nuclearmente as suas análises na sintaxe e na semântica e interpreta que o nome substantivo, o nome adjetivo e o verbo são os elementos básicos para nos adentrarmos nesta hipótese de explicação linguística. O significado do verbo condiciona a sua valência, que é o número de lugares que têm de ser preenchidos pelos atantes para que o predicado verbal e também a cláusula consigam ter uma significação completa. A existência de quatro tipos de predicados verbais (avalentes, monovalentes, bivalentes e trivalentes) e a existência também de até dez tipos de elementos atanciais com diferentes modos de se relacionarem transitivamente com o verbo permite adentrarmo-nos, dentro da valência denominada variável, em como se manifesta esta do ponto de vista dialetal.

Assim, no presente trabalho foram expostos três caminhos para ilustrarem que uma investigação dialetológica que adoptar como corrente teórica a GV se torna aplicável de três maneiras fundamentais: (i) na modificação do número de argumentos nos verbos do ponto de vista territorial, conforme se viu no caso de verbos avalentes impessoais que acrescentam um $\mathrm{A}_{1}$ ou de verbos qual guardar que reduzem os seus atantes a só $\mathrm{A}_{1}$; (ii) na mudança agora não já de número mais de tipos de elementos atanciais, conforme se pôde verificar para esquecer, lembrar e ainda outros predicados verbais; e (iii) na análise dos traços sintático-semânticos dos atantes capazes de alterarem as suas caraterísticas de construção valencial, qual é o caso de acontecer, meter etc.

Daqui, de uma perspetiva mais clássica da geolinguística, só restará a verificação cartográfica dessas modificações dialetais, se houver a possibilidade, mas também a extração de dados que digam respeito à frequência real de utilização de determinadas possibilidades de construção atancial com os mesmos verbos. Ainda, de um ponto de vista mais atual, para uma adequada consecução das metas marcadas em (i-iii) no anterior parágrafo, deverão ter-se em consideração outros fatores de variação, qual a adscrição social, a idade, o registo, o sexo, etc., todos eles capazes de nos oferecerem uma maior informação sobre como se apresentam as modificações sintáticas. E nestas, conforme tentámos constatar com o contributo que agora chega ao seu fim, também a GV pode servir de grande ajuda.

\section{Referências bibliográficas}

Ali, Manuel Said (19645 [1931]): Gramática Histórica da Língua Portuguesa. São Paulo: Melhoramentos. Alvar, Manuel (dir.) (1999): Manual de Dialectología Hispánica. Barcelona: Ariel.

Álvarez, Rosario e Xosé Xove (2002): Gramática da Lingua Galega. Vigo: Galaxia.

Amaral, Vasco Botelho de (1945): Meditações Críticas sôbre a Língua Portuguesa. Estudos de Estética e Psicologia da Linguagem. Problemas da Moral do Estilo. Personalidade do Idioma Português. Lisboa: Edições Cama.

Báez San José, Valerio (1988): Fundamentos Críticos de la Gramática de Dependencias. Madrid: Síntesis. Benedet, María Jesús (2006): Acercamiento Neurolingüístico a las Alteraciones del Lenguaje. Vol. I. Fundamento Teórico de la Neurolingüistica. Procesamiento Normal del Lenguaje. Vol. II. Neurolingüística. Aplicaciones de la Ciencia. Madrid: Editorial EOS.

Buescu, Maria Leonor Carvalhão (1984): Monsanto. Etnografía e Linguagem. Lisboa: Presença.

Busse, Winfried e Mário Vilela (1986): Gramática de Valências. Apresentação e Esboço de Aplicação à Lingua Portuguesa. Coimbra: Livraria Almedina.

Campbell, Lyle (1972): “Is a generative Dialectology possible?”, Orbis 21, pp. 285-298.

Chambers, Jack K. e Peter Trudgill (1994): La dialectología. Barcelona: Visor.

Cidrás Escáneo, Francisco Antonio e Francisco Dubert García (2017): “A gramática galega, un río de curso curto e sinuoso. Panorama histórico dos estudios gramaticais sobre o galego", em Lingüística Galega. A Contribución do Instituto da Lingua Galega (LaborHistórico 3/1), pp. 111-125. 
(2005): “A sintaxe na gramática: problemas de descrición e problemas de prescrición”, em R. Álvarez e H. Monteagudo (eds.), Norma Lingüística e Variación. Unha Perspectiva desde o Idioma Galego. Santiago de Compostela: Consello da Cultura Galega / Instituto da Lingua Galega, pp. 335-357.

Cintra, Luís Filipe Lindley (1995² [1983]): Estudos de Dialectologia Portuguesa. Lisboa: Sá da Costa.

Clive, Upton e John David Allison Widdowson (2006² [1996]): An Atlas of English Dialects. New York: Routledge.

Dias, Augusto Epiphanio da Siva (1954³ [1918]): Syntaxe Histórica Portuguesa. Lisboa: Livraria Classica Editora.

Dik, Simon C. (1989): The Theory of Functional Grammar. Part. I. The Structure of the Clause. Dordrecht: Foris Publications.

Dubois, Jean; Mathée Giacomo, Louis Guespin, Christiane Marcellesi, Jean-Baptiste Marcellesi e JeanPierre Mevel (20018 [1973]): Dicionário de Lingüistica. São Paulo: Cultrix.

Fernández Rei, Francisco (2003 ${ }^{3}$ [1991]): Dialectoloxía da Lingua Galega. Vigo: Xerais.

Florêncio, Manuela (2001): Dialecto Alentejano. Contributos para o seu Estudo. Lisboa: Colibri.

Francis, W. Nelson (1989² [1983]): Dialectology. An Introduction. London: Longman.

Freixeiro Mato, Xosé Ramón (2006² [1998-2003]): Gramática da Lingua Galega. Vol. I. Fonética e Fonoloxía. Vol. 2. Morfosintaxe. Vol. 3. Semántica. Vol. IV. Gramática do Texto. Vigo: A Nosa Terra.

(2013): Estilística da Língua Galega. Vigo: A Nosa Terra.

Garcia, Idalina Serrão (1979): O Falar da Glória do Ribatejo. Lisboa: Monumental.

Gimeno Menéndez, Francisco (1990): Dialectología y Sociolingüística Españolas. Alicante: Universidade de Alicante.

ILG [= Instituto da Lingua Galega] (1990 / 1995 / 1999 / 2003 / 2005): Atlas Lingüistico Galego. Vol. I. Morfoloxía Verbal. Vol. II. Morfoloxía non Verbal. Vol. III. Fonética. Vol. IV. Léxico. Tempo Atmosférico e Cronolóxico. Vol. V. Léxico. O Corpo Humano (I). Corunha: Fundación Pedro Barrié de la Maza.

Jódar Vicente, Mercè (coord.) (2005): Trastornos del Lenguaje y la Memoria. Barcelona: Editorial UOC.

Lapa, Manuel Rodrigues (198411 [1945]): Estilistica da Língua Portuguesa. Coimbra: Coimbra Editora.

López Leizán, Clemente (1999): “A impersonalidade do verbo chover en galego medieval. Unha aproximación”, Cadernos de Lingua 19, pp. 111-122.

Lyons, John (1993³ [1984]): Introducción al Lenguaje y a la Lingüistica. Barcelona: Teyde.

Mariño Paz, Ramón (1994): "Historia da lingua, lingüística histórica e dialectoloxía. Notas para a investigación e a docencia destas materias", Cadernos de Lingua 9, pp. 5-25.

Marquilhas, Rita (1996): "Mudança linguística", em I. Hub Faria, Emília Ribeiro Pedro, Isabel Duarte e Carlos A. M. Gouveia (orgs.), Introdução à Linguística Geral e Portuguesa. Lisboa: Caminho, pp. 563-588.

Martins, Ana Maria (coord.) (2000-): CORDIAL-SIN: Corpus Dialectal para o Estudo da Sintaxe / Syntaxoriented Corpus of Portuguese Dialects. Lisboa: Centro de Linguística da Universidade de Lisboa, http://www.clul.ulisboa.pt/en/10-research/314-cordial-sin-corpus [consulta: 11/09/2019].

Moulton, William G. (1960): "The short vowel systems of nothern Switzerland: a study in structural dialectology", Word 16, pp. 155-183.

MS = Pensado, José Luís (ed.) (1958): Miragres de Santiago (Revista de Filologia Española, Anejo LXVIII). Madrid: Consejo Superior de Investigaciones Científicas.

Neves, Maria Helena de Moura (1999): Gramática de Usos do Português. São Paulo: UNESP.

Peres, João Andrade e Telmo Móia (1995): Áreas Críticas da Língua Portuguesa. Lisboa: Caminho.

Perini, Mário A. (2008): Estudos de Gramática Descritiva. As Valências Verbais. São Paulo: Parábola.

Porto Dapena, José-Álvaro (1997³ [1992]): Complementos Argumentales del Verbo: Directo, Indirecto, Suplemento y Agente. Madrid: Arco/Libros.

Pottier, Bernard (1999² [1996]): "Dialectología y gramática", en M. Alvar (dir.), Manual de Dialectología Hispánica. El Español de España. Barcelona: Ariel, pp. 31-36.

RAG / ILG [= Real Academia Galega e Instituto da Lingua Galega] (2003 ${ }^{18}$ [1982]): Normas Ortográficas e Morfolóxicas da Lingua Galega. Corunha: Real Academia Galega.

Rábade Castiñeira, Xoán Carlos (2003): "Algunhas propostas sobre as unidades, relacións e funcións sintácticas”, Revista Galega de Filoloxía 4, pp. 115-152.

Rodríguez Guerra, Alexandre (1997): “Aspectos da transitividade galega: os complementos en 'en'”, em B. Fernández Salgado (ed.), Actas do IV Congreso Internacional de Estudos Galegos (Universidade de Oxford, 26-28 de setembro 1994). Oxford: Centro de Estudios Galegos, vol. I, pp. 343-352. 
RPT = Fontes, Manuel da Costa (1987): Romanceiro da Província de Tras-os-Montes (Distrito de Bragança). Coligido com a Colaboração de Maria-João Câmara Fontes. Prefácio de Samuel G. Armistead e Joseph H. Silverman. Transcrições Musicais de Israel Katz. Coimbra: Universidade de Coimbra.

Saco Arce, Juan Antonio (1868): Gramática Gallega. Lugo: Imprenta de Soto Freire.

Sánchez Rei, Xosé Manuel (2010): O Complemento Preposicional en Galego. Análise desde a Gramática de Valencias. Monografia 6 da Revista Galega de Filoloxía. Corunha: Área de Filologia Galega e Portuguesa da Universidade da Corunha.

(2011): Lingua Galega e Variación Dialectal. Ames: Laiovento.

(2013): "Os nomes de lugar e a dialectoloxía: algunhas consideracións sobre as variantes locais do galego e a súa atestación nos topónimos", Verba, 40, pp. 389-414.

(2016): "Aproximação geral aos marcadores discursivos de controlo de contato" em X. M. Sánchez Rei e M. A. Marques (eds,), As Ciências da Linguagem no Espaço Galego-Português. Braga: Instituto de Letra e Ciências Humanas da Universidade do Minho, pp. 99-128.

Segura, Luiza (2013): "Variedades dialetais do português europeu", em E. Buzaglo Paiva Raposo, M. F. Bacelar do Nascimento, M. A. Coelho da Mota, L. Segura e A. Mendes (orgs.), Gramática do Português. Lisboa: Fundação Calouste Gulbenkian, vol. I, pp. 83-142.

Silva-Corvalán, Carmen (1989): Sociolingüistica. Teoría y Análisis. Madrid: Alhambra.

Simão, Teresa (2011): O Falar de Marvão. Pronúncia, Vocabulário, Alcunhas, Ditados e Provérbios Populares. Lisboa: Colibri.

Troubetzkoy, Nikolaï Sergueïevitch (1964): Principles de Phonologie. Paris: Klincksieck.

Vasconcellos, José Leite de (1928): Opúsculos. Vol. II. Dialectologia. Coimbra: Universidade de Coimbra. (1985): Opúsculos. Vol. VI. Dialectologia. Lisboa: Imprensa Nacional-Casa da Moeda.

(19873 [1901]): Esquise d'une Dialectologie Portugaise. Lisboa: Instituto de Investigação Científica.

Viaplana, Joaquim (2002): Dialectologia. València: Universitat de València.

Vilela, Mário (2002): Metáforas do Nosso Tempo. Coimbra: Livraria Almedina.

Vilela, Mário e Ingedore Villaça Koch (2001): Gramática da Língua Portuguesa. Gramática da Palabra. Gramática da Frase. Gramática do Texto / Discurso. Coimbra: Livraria Almedina.

Weinrich, Uriel (1954): "Is a structural dialectology possible?", Word 10, pp, 388-400. Reeditado em Harold Byron Allen e Michael D. Linn (eds.) (1986): Dialect and Language Variation. New York: Academic Press, pp. 20-34. 
